\title{
Rifamycin SV in the Treatment of Lepromatous Leprosy
}

\author{
DILTOR V.A. OPROMOLLA $\left({ }^{0}\right)$, LAURO DE SOUZA LIMA $\left({ }^{00}\right)$ and \\ GABRIELE CAPRARA $\left({ }^{000}\right)$
}

Rifamycin SV belongs to a family of antibiotics, the rifamycins, isolated in $195^{8}$ by Sensi et al. and produced by Streptomyces mediterranei, nova species $\left(\mathbf{2 3 - 2 5}^{2}\right)$. Their chemical structure is entirely different from that of any other known antibiotic $\left({ }^{18}\right)$.

The pharmacological characteristics of Rifamycin $\mathrm{SV}$, as demonstrated in animals and humans, are described in details in numerous papers (e.g. 1, 2, 4, 8, 9, 10, 30).

This antibiotic shows, in vitro, a marked antimicrobial activity against gram-positive microorganisms at $0.002-0.05 \mathrm{mcg} / \mathrm{ml}$ concentrations, while against gram-negative microorganisms much higher concentrations are required. Against human and bovine varieties of Mycobacterium tuberculosis, Rifamycin $\mathrm{SV}$ is active at concentrations around $0.05 \mathrm{mcg} / \mathrm{ml}$, determining arrest of the bacterial multiplication, rapidly followed by marked bacteriocidal effects. Its in vitro activity against tubercle bacilli is higher than that of Streptomycin and PAS and comparable only to that of INH $(7,14,22,31,32)$.

In human tuberculosis, very satisfactory results have been obtained by topical application $(5,12,13,15,20,26,32)$; by intramuscular administration limited results have been obtained $(5,12,13)$, while treatment with intravenous infusions seems to be promising $(5,6,29)$.

The possible usefulness of Rifamycin SV in the treatment of leprosy has been suggested by the similarities believed to exist between the causative agent of this disease and that of tuberculosis, by the high in vitro activity of the antibiotic against the latter and by its clinical effectiveness in certain tuberculous conditions.

A relatively high dosage was used in our trial because of the lack of experimental data on the basis of which any reasonable assumption as to the clinically effective dosage could be made, and also because the distribution studies carried out in animals have shown that the concentrations obtainable in the skin after systemic administration are somewhat low in comparison with those obtainable in other tissues $(9,10)$. In this connection, however, it should be noted that appreciable and long-lasting levels of antibiotic have been experimentally demonstrated in superficial inflammatory foci such as the 'granuloma pouch' exudate $\left({ }^{9}\right)$; a significance of this fact with reference to the distribution of Rifamycin SVin skin lepromatous lesions in man is possible, although clearly hypothetical on the basis of the available evidence.

The intramuscular route of administration was chosen, as it is known that when the antibiotic is administered orally, therapeutically active concentrations can be obtained in the biliary tract, but usually not in the systemic circulation, while after intramuscular administration they reach a peak after I-2 hours and last for many hours, depending on the administered dose. A sodium salt aqueous solution was used throughout, containing polyvinylpyrrolidone for better local tolerance.

Some preliminary results obtained in our clinical trial have been previously reported $(16,17,27)$ : an assessment of the results of this clinical trial after a longer period of treatment is the subject of the present paper.

In the meanwhile, the therapeutic interest of Rifamycin SV in the treatment of leprosy has also been confirmed by the observation of other clinical investigators $(\mathbf{3}, 11,21)$.

$\left({ }^{0}\right)$ Leprologist, Sanatorium 'Aymorés', and Assistant in Microbiology, Faculty of Odontology, Bauru, São Paulo (Brazil).

(00) Professor of Leprology, Faculty of Medicine, University of Sorocaba, and Faculty of Hygiene and Public Health, University of São Paulo (Brazil).

(000) Al. da Santos, 734, São Paulo (Brazil). 
MATERIAL AND METHODS

Eleven leprosy patients in advanced stage were submitted to the trial. Eight of them presented small or medium-size disseminated or isolated tubercles; in the other three there was a moderate, diffused infiltration.

One patient (No. 7) showed lesions which could be clinically classified in the 'borderline' group. We realize that objection could be raised as to the inclusion in a therapeutic trial of patients suffering from borderline leprosy, as these subjects usually react very rapidly and satisfactorily to any specific treatment. However, the bacterial and biopsy findings demonstrated that this case had to be eventually classified as belonging to the lepromatous type, and thus its inclusion in the caselist appears entirely justified.

Nine of these patients had not received any previous anti-leprosy treatment; two had discontinued a previous treatment, and presented a relapse.

Ages ranged from i 8 to 54 years; three patients were females. The evolution of the cases was checked by clinico-dermatological examinations carried out at least once a month; photographs of the patients were taken on these occasions.

Each month a bacterial index was determined on the mucus and on the skin lesions. From a quantitative standpoint, the amounts of alchohol-acid-fast bacilli (AAFB) found in the smears were evaluated with a score (number of pluses), varying from o to 4; o indicates no bacilli, $(+)$ rare bacilli, and $(++),(+++)$, and $(++++)$ from moderate to very high amounts of bacilli.

The mucus index expresses the average of the scores attributed to the material collected from each nostril.

The skin lesion index was calculated as the average of the scores attributed to the material obtained from the most active skin lesions.

From a qualitative standpoint, the alcoholacid-fast bacilli (AAFB) encountered were classified as follows: $(\mathrm{T})=$ typical bacilli; $(\mathrm{G})=$ granular bacilli.

The abbreviation ( $\mathrm{R})$, which accompanies sometimes this classification, indicates that the form in question was represented only by rare bacilli.

The cases were classified as improved when the bacterial index became less or the bacillary regression was predominant; as deteriorated when the bacterial index was, even slightly, higher.

Biopsies were taken at the beginning of treatment and at different time intervals. The slides were prepared with haematoxylin-eosin and with the Ziehl-Neelsen method.

The evaluation was based on the following criteria: modifications of the lepromatous infiltration, quantitative and qualitative bacterial variations.

The infiltration was considered improved in the presence of the regressive lepromatous structures described by Rath de Souza and Alayon ( ${ }^{19}$ ) and characterized by Virchow's cells and increase of intracellular fat.

Concerning the quantitative bacteriology of the infiltrates, it was impossible to work out reliable bacterial indices; only a rough comparison of the quantities of bacilli found in the examined lesions, expressed as scores (number of pluses), was carried out.

Concerning the qualitative bacilloscopy, the incidence of bacillary degeneration was evaluated.

Haemoglobin determinations, blood counts and urinalyses were also carried out at various intervals.

The general treatment schedule was I daily Rifamycin SV dose of I g., divided into two $500 \mathrm{mg}$ i.m. injections, I every $\mathrm{I} 2$ hours; in 2 cases a $0.5 \mathrm{~g}$. daily dose was also tried during part of the treatment period. The duration of treatment was 5 months in 2 cases, $I 0$ in $I$, I $I$ in I case, and $I 2$ in 7 cases.

For evaluating the results, a blind-examination was utilized, with the co-operation of leprosy specialists from the State Leprosy Department of São Paulo. Two evaluations were generally carried out: one after 6 months and one at the end of treatment.

\section{RESULTS}

Case records are of course available of the I I leprosy patients but because the full details would absorb considerable space we here include 3 tables of results.

D IS G U S I I N

Clinically, all the cases could be considered as improved (Table I). This improvement consisted in diminution of the diffused infiltration; disappearance of the diffused erythema, of the 
Clinical results of treatment with Rifamycin SV in I cases of leprosy

\begin{tabular}{|c|c|c|c|c|c|}
\hline Case №. & Name & $\begin{array}{l}\text { Duration of } \\
\text { treatment } \\
\text { (days) }\end{array}$ & daily & total $^{\circ}$ & Clinical result \\
\hline I & L.C. & 372 & I & 371 & $\begin{array}{l}\text { improved, with } \\
\text { erythema nodosum }\end{array}$ \\
\hline 2 & A.C. & 370 & I & $3^{68}$ & $\begin{array}{l}\text { improved, with } \\
\text { erythema nodosum }\end{array}$ \\
\hline 3 & J.B. & 360 & I & 355 & $\begin{array}{l}\text { improved, with } \\
\text { erythema nodosum }\end{array}$ \\
\hline 4 & G.A. & 147 & $0.5^{-1}$ & 89 & improved \\
\hline 5 & O.O. & I 54 & $0.5^{-1}$ & 103 & improved \\
\hline 6 & J.F.M. & 335 & I & 335 & improved \\
\hline 7 & M.A.P. & $34^{2}$ & I & 340 & improved \\
\hline 8 & M.J.M.O. & 357 & I & $35^{\circ}$ & improved \\
\hline 9 & B.G. & 352 & I & 352 & improved \\
\hline Io & E.L.S. & 377 & I & $37 \mathrm{I}$ & improved \\
\hline I I & P.S. & 284 & I & 279 & improved \\
\hline
\end{tabular}

${ }^{\circ}$ In most cases, the total dose is slightly lower than the value which can be calculated from the duration of treatment and the daily dose owing to temporary discontinuance of treatment (cases No. 3 and 5 ) or to occasional omission of some injections.

papules and maculo-papules; flattening of the tubercles and nodules, in many instances with disappearance of the latter. The intensity and rapidity of the regressive phenomena, which were generally evident already in the first ${ }_{5} 5$ days and reached a peak within the first three months of treatment, were particularly impressive. The improvements which occurred after this period were, in our opinion, not quite as rapid, due partly to the progressively reduced number of clinically active lesions and partly to the tendency of the lepromas to fibrosis, manifested in some patients.

Another interesting aspect is that of the reactive phenomena, of the erythema nodosum type, observed during the treatment.

Cases Nos. I, 2, 3 and ro presented erythema nodosum outbreaks of low intensity, which varied from one single nodule in one case to a limited number of cutaneous elements with regional adenopathy, fever and moderate deterioration of the general condition. None of these patients had to interrupt the treatment, except for case No. 3, in whom Rifamycin SV was temporarily discontinued (five days) because the patient presented reactive nodules on the injection site.

Case No. 7 showed a recurrent but transient exacerbation of the specific cutaneous lesions during treatment.

On the other hand, case No. 4 showed early in the first weeks of treatment an acute episode of erythrodermia and oedema of hands and feet ('pseudo-exacerbation'); following this episode and possibly owing to the antibiotic effect, his immuno-clinical condition changed radically, with a remarkable improvement of the prognosis. Unfortunately the treatment could not 
TABLE 2

Results of bacilloscopic examination of mucus and skin lesions before and after treatment with Rifamycin SV in II cases of leprosy

\begin{tabular}{|c|c|c|c|c|c|c|}
\hline \multirow[b]{2}{*}{ Case $\mathcal{N} o}$. & \multicolumn{2}{|c|}{ Mucus } & \multicolumn{4}{|c|}{ Lesion } \\
\hline & $\begin{array}{l}\text { Initial } \\
\text { index }\end{array}$ & $\begin{array}{l}\text { Final } \\
\text { index }\end{array}$ & Conclusion & $\begin{array}{l}\text { Initial } \\
\text { index }\end{array}$ & $\begin{array}{l}\text { Final } \\
\text { index }\end{array}$ & Conclusion \\
\hline I & o & o & unchanged & 2.6/RT,G & $3.6 / \mathrm{RT}, \mathrm{G}$ & deteriorated \\
\hline 2 & $3 / \mathrm{T}$ & o & improved & $3 / \mathrm{T}, \mathrm{G}$ & $2 / G$ & improved \\
\hline 3 & o & o & unchanged & $3.6 / \mathrm{T}, \mathrm{G}$ & $3.6 / \mathrm{T}, \mathrm{G}$ & unchanged \\
\hline 4 & $\mathrm{I} .5 \mathrm{~T}$ & o & improved & 3/T,RG & ı.6/RT,G & improved \\
\hline 5 & $3 / \mathrm{T}$ & o & improved & $\mathrm{I} \cdot 3 / \mathrm{T}, \mathrm{RG}$ & $2.3 / \mathrm{T}, \mathrm{G}$ & deteriorated \\
\hline 6 & $\mathrm{I} / \mathrm{G}$ & o & improved & $4 / \mathrm{T}, \mathrm{G}$ & 3/RT,G & improved \\
\hline 7 & o & o & unchanged & $3 \cdot 3 / \mathrm{RT}, \mathrm{G}$ & 3/RT,G & unchanged \\
\hline 8 & o & o & unchanged & $3 \cdot \mathrm{I} / \mathrm{RT}, \mathrm{G}$ & $2.5 / \mathrm{RT}, \mathrm{G}$ & improved \\
\hline 9 & I.5/T,RG & o & improved & $4 / \mathrm{T}, \mathrm{G}$ & I.3/RT,G & improved \\
\hline IO & o & o & unchanged & $2.5 / \mathrm{T}, \mathrm{G}$ & $2.3 / \mathrm{RT}, \mathrm{G}$ & improved \\
\hline I I & 2/T,RG & o & improved & 2.I/T,G & I.5/RT,G & improved \\
\hline
\end{tabular}

$\mathrm{R}=$ Rare bacilli, $\mathrm{T}=\mathrm{T}$ ypical bacilli, $\mathrm{G}=$ Granular bacilli

be continued in this patient because he was emaciated and suffering from mega-oesophagus and refused to go on with the intramuscular injections.

With reference to bacilloscopy, an evaluation may be made on the results of the examination both of the nasal mucus and of the cutaneous lesions.

The mucus became bacterioscopically negative in six cases (Table 2); the remaining five cases, which were already negative before treatment, persisted unaltered.

The disappearance of the bacilli from the mucus was observed within 2 months in one case (No. I I), 4 months in three cases (No. 4, 5, 9), 9 months in one case (No. 5) and I I months also in one case (No. 2).

Examination of the cutaneous lesions revealed that the bacilloscopic picture after treatment was improved in seven cases, unchanged in two, deteriorated in two, in comparison with the picture observed before treatment.

In this connection it should be noted that in both the cases classified as deteriorated the increase of the bacterial index was moderate; furthermore, in one of them (No. I) a persistence and in the other (No. 5) a relative increase of the granular forms were observed.

The bacilloscopic changes did not always proceed in a parallel way with the remarkable clinical results obtained. One of the reasons for this fact could reside in the defective evaluation criteria, since the bacterial index does not allow a satisfactory estimate of the actual numbers of infecting bacilli.

On the other hand, keeping in mind the enormous quantity of bacilli per $\mathrm{mm}^{3}$ of infected skin it seems clear that, even if the microorganisms were no longer viable after the antibiotic treatment, a long period of time would be necessary for completing the elimination of this bacterial material.

As far as the histopathological examinations are concerned (Table 3), all the ro cases who were evaluated at the beginning of treatment and after different time intervals were improved according to the previously mentioned criteria.

With reference to the bacilloscopic evaluation

\section{26 Leprosy Review}


TABLE 3

Results of histopathological examination of skin lesions before and during treatment with Rifamycin SV in ro cases of leprosy.*

Histopathological results

\begin{tabular}{|c|c|c|c|c|c|c|c|c|}
\hline \multirow{3}{*}{$\begin{array}{l}\text { Case No. } \\
\mathrm{I}\end{array}$} & \multirow{3}{*}{$\begin{array}{l}\text { I st Biopsy } \\
\text { Intense } \\
\text { lepromatous } \\
\text { infiltration }\end{array}$} & \multirow{3}{*}{$\begin{array}{ll} & M \\
& t r \\
\text { 2nd Biopsy } & \text { be } \\
& B \\
\begin{array}{l}\text { Leproma in } \\
\text { regression }\end{array}\end{array}$} & \multirow{2}{*}{$\begin{array}{l}\text { Months of } \\
\text { treatment } \\
\text { between the } 2 \\
\text { Biopsies }\end{array}$} & \multirow{2}{*}{$\begin{array}{l}\text { Quantitative } \\
\text { bacilloscopy } \\
\text { I st }\end{array}$} & \multirow{3}{*}{$\frac{2 n d}{+++}$} & \multicolumn{2}{|c|}{$\begin{array}{l}\text { Qualitative } \\
\text { bacilloscopy }\end{array}$} & \multirow{3}{*}{$\begin{array}{c}\text { Conclusions } \\
\text { improved }\end{array}$} \\
\hline & & & & & & I st & 2nd & \\
\hline & & & 5 & ++++ & & $\mathrm{T} / \mathrm{RG}$ & $\mathrm{RT} / \mathrm{G}$ & \\
\hline 2 & Leproma & $\begin{array}{l}\text { Intense lepro- } \\
\text { matous infil- } \\
\text { tration in } \\
\text { regression }\end{array}$ & o- 4 & ++++ & ++ & $\mathrm{T} / \mathrm{RG}$ & $\mathrm{RT} / \mathrm{G}$ & improved \\
\hline 3 & $\begin{array}{l}\text { Intense } \\
\text { lepromatous } \\
\text { infiltration }\end{array}$ & $\begin{array}{l}\text { Leproma in } \\
\text { regression }\end{array}$ & 4 & ++++ & +++ & $\mathrm{T} / \mathrm{RG}$ & $\mathrm{RT} / \mathrm{G}$ & improved \\
\hline 5 & $\begin{array}{l}\text { Intense } \\
\text { lepromatous } \\
\text { infiltration in } \\
\text { regression }\end{array}$ & $\begin{array}{l}\text { Moderate } \\
\text { lepromatous } \\
\text { infiltration in } \\
\text { regression }\end{array}$ & $\begin{array}{l}\text { s } \\
\text { in }\end{array}$ & ++ & + & $\mathrm{T} / \mathrm{RG}$ & $\mathrm{RT} / \mathrm{G}$ & improved \\
\hline 6 & $\begin{array}{l}\text { Moderate } \\
\text { lepromatous } \\
\text { infiltration in } \\
\text { regression }\end{array}$ & $\begin{array}{l}\text { Moderate } \\
\text { lepromatous } \\
\text { infiltration in } \\
\text { regression }\end{array}$ & $\begin{array}{l}\text { s } \\
\text { in }\end{array}$ & +++ & ++ & G & G & improved \\
\hline 7 & $\begin{array}{l}\text { Moderate } \\
\text { lepromatous } \\
\text { infiltration }\end{array}$ & $\begin{array}{l}\text { Moderate } \\
\text { lepromatous } \\
\text { infiltration in } \\
\text { regression }\end{array}$ & in & ++++ & ++ & $\mathrm{T} / \mathrm{RG}$ & $\mathrm{RT} / \mathrm{G}$ & improved \\
\hline 8 & $\begin{array}{l}\text { Intense } \\
\text { lepromatous } \\
\text { infiltration }\end{array}$ & $\begin{array}{l}\text { Moderate } \\
\text { lepromatous } \\
\text { infiltration in } \\
\text { regression }\end{array}$ & in & +++ & + & $\mathrm{T} / \mathrm{RG}$ & $\mathrm{RT} / \mathrm{G}$ & improved \\
\hline 9 & Leproma & $\begin{array}{l}\text { Leproma in } \\
\text { regression }\end{array}$ & $4 \frac{1}{2}$ & +++ & ++++ & $\mathrm{T} / \mathrm{RG}$ & $\mathrm{RT} / \mathrm{G}$ & improved \\
\hline Io & $\begin{array}{l}\text { Intense } \\
\text { lepromatous } \\
\text { infiltration }\end{array}$ & $\begin{array}{l}\text { Intense } \\
\text { lepromatous } \\
\text { infiltration in } \\
\text { regression }\end{array}$ & in & ++++ & +++ & $\mathrm{T} / \mathrm{RG}$ & $\mathrm{RT} / \mathrm{G}$ & improved \\
\hline I I & $\begin{array}{l}\text { Intense } \\
\text { lepromatous } \\
\text { infiltration }\end{array}$ & $\begin{array}{l}\text { Moderate } \\
\text { lepromatous } \\
\text { infiltration in } \\
\text { regression }\end{array}$ & n & +++ & + & $\mathrm{T} / \mathrm{RG}$ & $\mathrm{RT} / \mathrm{G}$ & improved \\
\hline
\end{tabular}

*Carried out by Dr. P. H. de Mello, Head of the Pathology Division, Department of Leprosy Prophylaxis, São Paulo. 

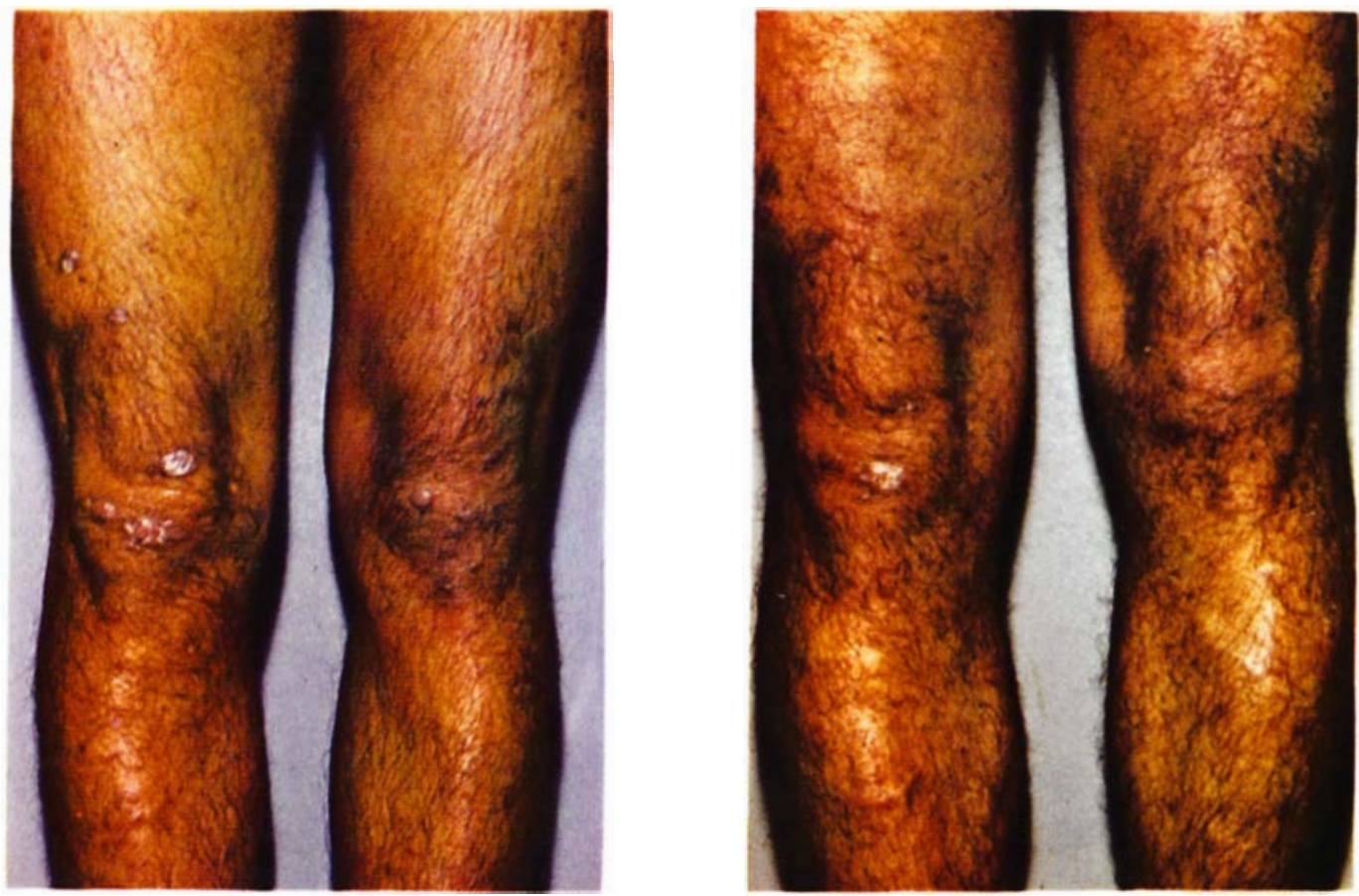

FIG I Case No. I at the beginning of treatment (a) and after 372 days of treatment (b).
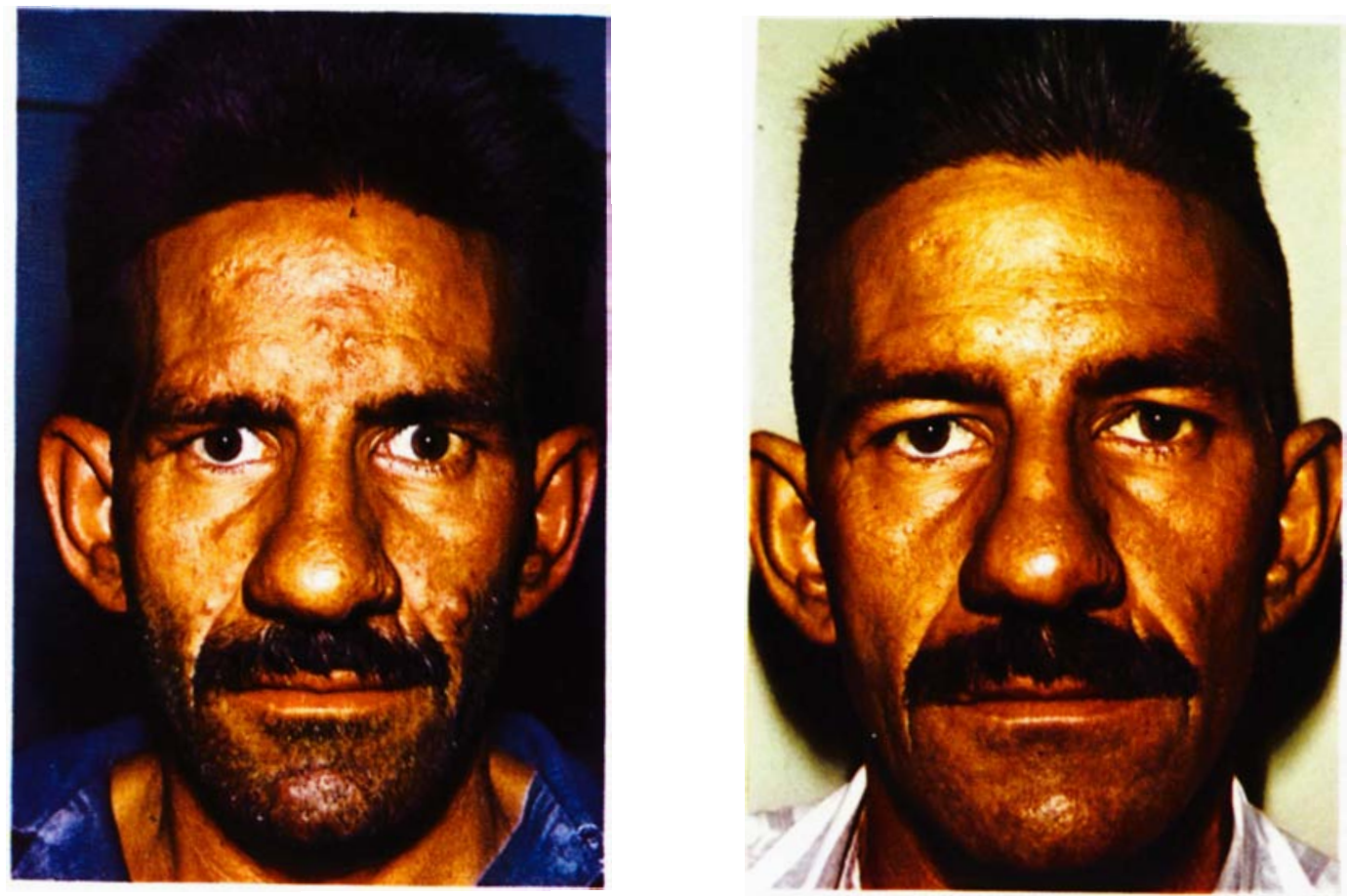

FIG 2 Case No. 2, at the beginning of treatment (a) and after 370 days of treatment (b). 

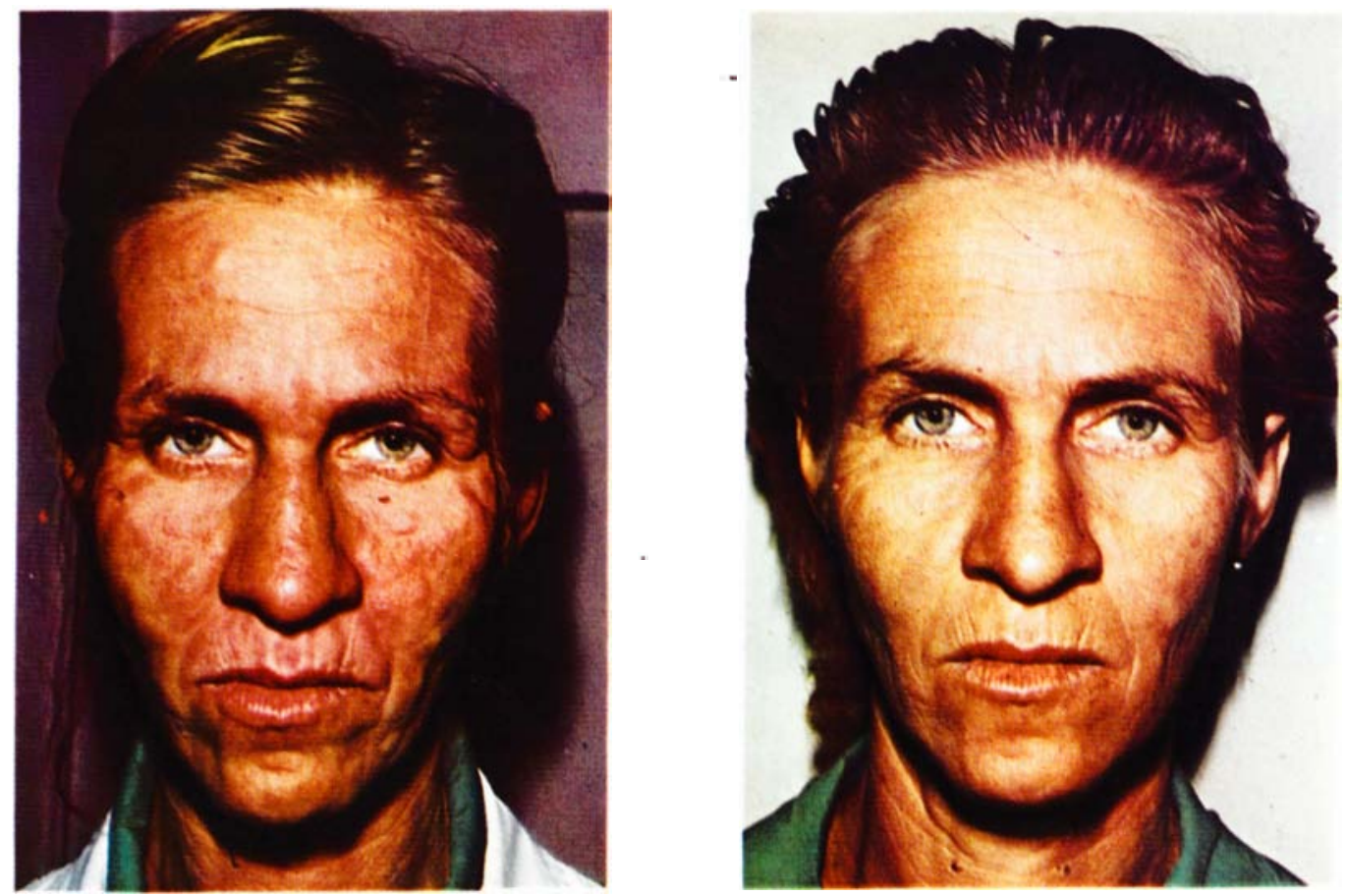

Fig 3 Case No. 7, at the beginning of treatment (a) and after 342 days of treatment (b).
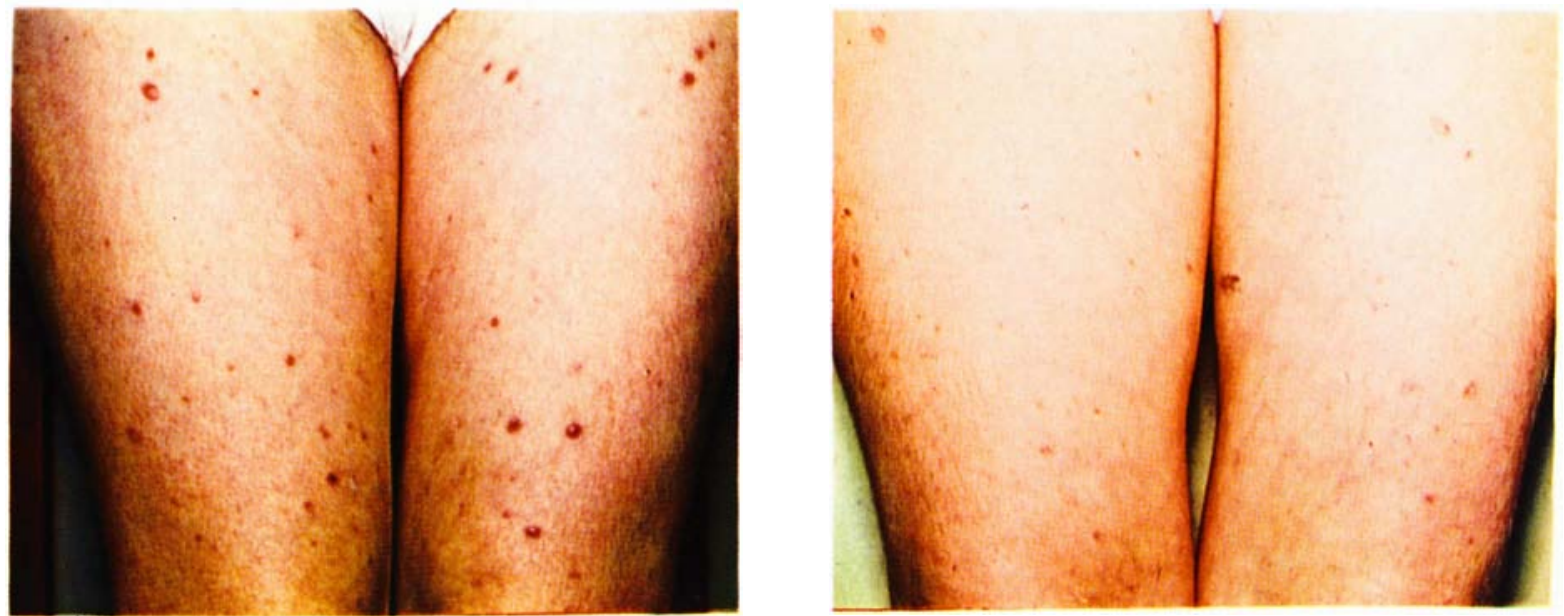

Fig 4 Case No. in, at the beginning of treatment (a) and after 377 days of treatment (b). 
of the biopsy specimens it should be noted, however, that its value appears to be clearly limited: in fact, the histopathological examinations were performed only at considerable intervals of time and thus could not give an exact estimation of the structural bacillary alterations due to the therapeutic influences. This seems to be especially true in consideration of the great number of lesions presented by each patient and of the possibility of a bacillary regression independent of any treatment.

It may therefore be stated that the available laboratory methods for evaluating the efficacy of an anti-leprosy treatment are still not very reliable. This is the reason why it seems preferable to rely more on the clinical results obtained and to attribute only a limited value to the bacilloscopic and histopathological data, even if they were favourable in the majority of the cases.

A further point which deserves a specific discussion is tolerance. The intramuscular administration of $500 \mathrm{mg}$. of Rifamycin $\mathrm{SV}$ every $\mathrm{I} 2$ hours was generally well tolerated : most patients received more than $350 \mathrm{~g}$. of antibiotic.

One case (No. 8) presented itching, which started around the injection site and then extended to other areas. This symptom persisted for 2 months, was controlled by antihistaminics, and subsequently disappeared although the antibiotic treatment had not been interrupted.

Another case (No. 2) presented an urticarial rash with itching which subsided spontaneously after one month, without discontinuing the treatment. We have no reasons to believe that the symptoms presented by these two patients were due to the drug.

Two cases (No. 5 and I I ) presented jaundice and gastric troubles with choluria and stained stools; neither fever, nor liver enlargement, nor erythema nodosum was noticed. The symptoms regressed within two weeks after discontinuance of the treatment and did not recur when the treatment was resumed.

In case (No. 5) the liver function tests (Lugol, Kunkel, thymol, Hanger and bilirubin serum levels) were positive. It is known that these tests can be positive in leprosy, even without jaundice; however, bilirubin serum levels $($ direct $=\mathrm{r} .6 ;$ indirect $=2.4 ;$ total $=4 \mathrm{mg} / \mathrm{ml})$ suggested the diagnosis of haemolytic jaundice.

On the other hand, similar symptoms have been observed with other anti-leprosy medications, such as sulphones, antibiotics or sulphonamides, regressing after discontinuance of the treatment and not recurring when the same treatment was resumed.

All cases, after 4 months of treatment, showed some hardening and slight pain at the injection site.

However, discontinuation of the treatment, was never required. No abscess occurred in any case.

An overall evaluation of the results obtained in the eleven patients reported here, who were all suffering from severe and long-lasting lepromatous leprosy, indicates that treatment with Rifamycin SV at the daily dose of $\mathrm{I} g$. can be considered both effective and well tolerated. In this connection, it may be worthy of mention that other independent trials carried out by us on outpatients ( ${ }^{28}$ ) and by other investigators who confirmed our results $(3,21)$ point to the possibility of adopting lower daily dosages, around $500 \mathrm{mg}$. daily. Furthermore, the usual promptness of the clinical improvement even in advanced cases suggests the possible interest of a short-term course of the antibiotic in the initial treatment of recent cases.

G O C L US I O N

(a) Rifamycin SV shows a remarkable effectiveness in the treatment of leprosy. The very favourable clinical results obtained open interesting perspectives in this field.

(b) The histopathological and bacilloscopic results do not always proceed in a parallel way with the clinical evolution.

(c) The absence of toxic effects, and of any other side effects which could be definitely attributed to the drug, shows that Rifamycin SV is excellently tolerated, except for some local reaction at the injection site after the fourth month of treatment. The incidence of reactive phenomena of the erythema nodosum type is moderate.

A GKN OW LEDGEMENT

The Authors wish to thank the Laboratorios Lepetit S.A. for the supply of Rifamycin SV.

S UM MAR Y

Eleven cases of lepromatous leprosy, in advanced stages of the disease, were treated for periods up to one year with Rifamycin SV. All the cases were submitted to clinical, bacilloscopic and histopathological examinations.

\section{I30 Leprosy Review}


Tolerance was excellent and the clinical results obtained, which were evident since the first weeks of treatment, were considered satisfactory.

Rifamycin SV has shown to possess a remarkable effectiveness in the treatment of leprosy.

\section{R E F E R E N C E S}

I. ACOcella, G. e muschio, R. Dimostrazione dell'esistenza, nell'uomo, di un circolo entero-epatico della rifomicina SV. Rif. Med., 75, i 490, I96 I.

2. GURCI, G. e NINNI, A. Indagini sperimentali sulla natura fisicochimica e sulla importanza pratica dei legami fra rifamicina SV, polivinilpirrolidone e proteine. Arch. Tisiol., r8, 190, 1963.

3. FARRIS, G. and BACCAREDDA-BOY, A. Observations on some modern anti-leprosy drugs. International Congress of Leprosy - Rio de Janeiro, September i 963.

4. Kluyskens, P. Absence de toxicité oto-vestibulaire de la rifamycine $\mathrm{SV}$ au point de vue expérimentale. Chemotherapia (Basel), 7, 1 70, 1963.

5. Lucchesi, m. Prime indagini sperimentali e cliniche sulla rifamicina $\mathrm{SV}$ in campo tubercolare. Arch. Tisiol., r8, 295, I 963 .

6. Lucchesi, M., BANCAle, A., PAllotta, G. e termine, A. Prime indagini cliniche in campo tubercolare sulla rifamicina SV somministrata per perfusione venosa. Ann. Ist. Forlanini, 22, 441, 1962.

7. Luridiana, n. e stringa, c. Azione 'in vitro' delle rifamicine B ed SV sul Mycobacterium tuberculosis. $G$. Ital. Tuberc., 16, 70, 1962.

8. lusena, m., SANTilli, E. e ACocella, G. Eliminazione biliare e livelli ematici di rifomicina B in soggetti normali ed in epatopazienti. Rif. Med., 29, 857, г 96 I.

9. MAFFi, G., SChiAtti, P. e BiAnchi, G. Distribuzione della rifamicina SV nell'organismo animale. Aspetti farmacologici e orientamenti terapeutici. Chemotherapia (Basel), 7, I 58 , I 963 .

io. MAFFi, G., Schiatti, P., BiAnchi, G. and SERralunga, M. G. Rifomycin XVIII. Pharmacological studies with rifomycin SV. Farmaco, ed. sci., r6, 235, 196 I.

i i. merklen, F. P. et cottenot, Fr. Essai d'un nouvel antibiotique, la rifamycine $\mathrm{SV}$ dans quelque cas de maladie de Hansen. Presse Méd., 72, 48, r 964.

12. monaldi, v. La rifamicina SV nella tubercolosi. Arch. Tisiol., r8, 345, 1963.

I3. monAldi, v. CURGi, g e NitTi, v. La rifomicina SV: nuovo antibiotico contro il micobatterio della tubercolosi. Arch Tisiol., r6, 36r, ig6r.

I 4. NITTI, v. Attività antimicobatterica della rifamicina SV in vitro. Arch. Tisiol., 18, I 77, I 963.
I 5. NitTi, v., virgilio, R. e NinNi, A. Le modificazioni del reperto bacillare nei tubercolotici sottoposti a trattamento con rifamicina SV. Arch. Tisiol., r8, 269, I963.

I6. OPROMOLLA, D. v. A. First results of the use of Rifamycin $\mathrm{SV}$ in the treatment of Lepromatous leprosy. International Congress of Leprosy - Rio de Janeiro, September I 963.

I 7. Opromolla, D. v. A. Primeiros resultados com a rifamicina na lepra lepromatosa. Rev. Bras. Leprologia, 3i, 53, I963 (com. prévia).

I8. PRELOG, v. Uber die Konstitution der Rifamycine. Chemotherapia (Basel), 7, 133, 1963.

I 9. RATh de souza, P. y alayon, F. L. Sobre a presença de lipidios nas lesoes cutâneas da lepra. Rev. Bras. Leprologia, I O, 37 I, I942.

20. REScigno, B. La posizione attuale della Rifamicina SV nella terapia dei processi tubercolari. Arch. Tisiol., r8, 238, I 963 .

2 I. RISI, J. B. Terapia Plurimedicamentosa na Lepra com a associaçoa da rifamicina SV. Rev. Serv. Nac. Tuberc., 7, 55 I, I 963 .

22. RIST, N. et GRumbach, F. Contribution à l'étude expérimentale de l'activité antituberculeuse de la rifamycine SV. Arch. Tisiol., 18, 304, I963.

23. SEnsi, P., Ballotta, R., GReco, M. A. and Gallo, G. G. Rifomycin. XV. Activation of rifomycin B and rifomycin O. Production and properties of rifomycin $\mathrm{S}$ and rifomycin SV. Farmaco, ed. sci., r6, I65, I96 I.

24. Sensi, P., margalith, P. and timbal, m. T. Rifomycin a new antibiotic. - Preliminary report. Farmaco, Ed. sci., I4, I 46, I 959 .

25. Sensi, P., timbal, m. т. and maffil, G. Rifomycin IX. Two new antibiotics of rifomycin family: rifomycin $\mathrm{S}$ and rifomycin SV. Preliminary report. Experientia, 16, 412, I96o.

26. sonaglioni, F. e Guidi, v. La rifamicina SV nella terapia degli empiemi tubercolari. Arch. Tisiol., 18, 248, I 963 .

27. SOUZA lima, L. de and opromol.la, D. v. A. First results on the treatment of leprosy with rifamycin SV. Chemotherapia (Basel), 7, 668, i963.

28. SOUZA LimA, L. de. Unpublished data.

29. TACQuet, A., macquet, V., Lelievre, G. et JONCRet, P. Tolerance et activité des perf usions veineuses de rifamycine SV dans le traitement de la tuberculeuse humaine. Arch. Tisiol., r8, 288, 1963.

30. TIMBAL, M. T. and BREgA, A. Rifomycin XVII. Rifomycin SV treatment of experimental infection. Farmaco, Ed. sci., r6, I9I, I96 I.

31. Timbal, m. T., Pallanza, R. and carniti, G. Rifomycin XVI. Bacteriological studies of rifomycin $\mathrm{SV}$ in vitro. Farmaco, Ed. sci., 16, I 81 , I96 I.

32. zORzoli, P., MONCALvo, F. e MOREO, G.C. Sull' attività antimicobatterica della rifamicina SV. Ricerche sperimentali 'in vitro' ed 'in vivo' ed impiego per via locale in campo clinico. G. Ial. Tuberc., r6, 226, I 963 . 